\title{
Coğrafya Öğretmen Adaylarının Sürdürülebilir Çevreye Yönelik Tutumları
}

\author{
Doç. Dr. Fatih AYDIN* \\ Karabük Üniversitesi, Edebiyat Fakültesi, Coğrafya Bölümü, 78050, Karabük Türkiye \\ Prof. Dr. Ülkü Eser ÜNALDI \\ Gazi Üniversitesi, Gazi Eğitim Fakültesi, Coğrafya Eğitimi Anabilim Dalı, Ankara, Türkiye
}

\section{Özet}

$\mathrm{Bu}$ araştırma, coğrafya öğretmen adaylarının sürdürülebilir çevreye ilişkin tutumlarını değerlendirmek amacıyla yapılmıştır. Araştırmaya 2011-2012 öğretim yılında Gazi Üniversitesi Gazi Eğitim Fakültesi Coğrafya Öğretmenliği programında öğrenim gören 139 öğrenci katılmıştır. Tarama modelinin uygulandığı bu araştırmada, veri toplama aracı olarak "Sürdürülebilir Çevre Tutum Ölçeği" kullanılmıştır. Verilerin analizinde aritmetik ortalama, standart sapma, t-testi, tek yönlü varyans analizi (ANOVA) ve Scheffe Testi kullanılmıştır. Araştırmada coğrafya öğretmen adaylarının sürdürülebilir çevreye ilişkin tutumlarının olumlu ve yüksek olduğu sonucuna ulaşılmıştır. Ayrıca, çalışmaya katılan coğrafya öğretmen adaylarının sürdürülebilir çevreye yönelik tutumlarının cinsiyet ve sınıf düzeyi değişkenlerine göre anlamlı farklılık gösterdiği tespit edilmiştir.

Anahtar Kelimeler: Çevre eğitimi; Coğrafya; Coğrafya öğretmen adayı; Sürdürülebilir çevre; Tutum. 


\title{
Geography Teacher Candidates’ Attitudes Towards Sustainable Environment
}

\begin{abstract}
This study was carried out to evaluate geography teacher candidates' attitudes towards sustainable environment. In the study, 139 students participated study from Geography Teacher Department of Gazi University, Educational Faculty in 2011- 2012 academic year. The study is based on survey model and Sustainable Environmental Attitude Scale was used as data gathering tool. In the analysis of the data, descriptive statistics along with arithmetic mean, standard deviation and in analyzing the differences of the participant views; $t$ test, ANOVA and Scheffe tests were used. As a result of the study, geography teacher candidates' attitudes towards sustainable environment have been found as positive and of high sensibility. Geography teacher candidates' attitudes towards sustainable environment indicated meaningful difference significance in terms of gender and class level variables.
\end{abstract}

Keywords: Environment education; Geography; Geography teacher candidates; Sustainable environment; Attitude.

\section{Extended Summary}

\section{Purpose}

In this study, it has been to determine geography teacher candidates’ attitudes towards sustainable environment.

1. What are geography teacher candidates' attitudes towards sustainable environment?

2. Do geography teacher candidates' attitude scores towards sustainable environment show a meaningful difference according to gender and class levels? 


\section{Method}

Research field of the study is geography teacher candidates attending Geography Departments of Educational Faculties in Turkey and the study group of the research is composed of totally 139 students attending Geography Teaching Department at Gazi Educational Faculty in 2011-2012 Spring Term. To determine geography teacher candidates' attitudes towards environment, the inventory developed by Y1ld1z (2011) was used. To determine the reliability of the inventory specialists' views were taken and Cronbach's alpha reliability coefficient of the questionnaire was found (0.91), KMO coefficient (0.84), and the Bartlett test value was found (.000), respectively.

\section{Findings}

The arithmetic average and standard deviation of students' attitudes towards sustainable environment were determined as 4.22 and 0.93 respectively. According to this finding, geography teacher candidates' attitudes towards sustainable environment have been found as positive and of high sensibility. It has been that the average of female students' scores according to sustainable environment inventory is 119.054 , male students' average is 110.726 .

According to independent groups t-test results, there is a meaningful difference between students' genders and their attitude scores towards sustainable environment $[t(137)=3.473 ; p<.0 .05]$. This finding can be evaluated as there is meaningful difference among geography teacher candidates’ attitudes towards geography teaching and gender variables. 
It has been seen that the score average of first grades' sustainable environment attitude is 120.233, second grades' is 111.114, third grades' is 117.214 , fourth grades' is 108.000 and fifth grades' average score towards sustainable environment is 115.733. According to the results of "ANOVA" carried out to determine whether there is statistically meaningful difference or not among groups of geography teacher candidates' attitude scores in regard to sustainable environment, it has been seen that there is meaningful difference according to class levels. In order to determine which group averages caused this difference, "Scheffe test" was applied and there has been found difference between sustainable environment attitude scores between first and fourth grades.

\section{Discussion and Conclusion}

In this study, it has been determined that geography teacher candidates' attitudes towards sustainable environment are positive and at high level. In the other works on attitudes for sustainable environment in different fields (Ruff \& Olson, 2009; Tuncer, 2008; Tuncer et al., 2005, 2005; Şahin \& Erkal, 2010; Y1ld1z, 2011) as well as other studies on attitudes, sensitivities and literacy of teacher candidates and university students (Akbaş, 2007; Aydın, 2010; Aydın \& Çepni, 2010; Altınöz, 2011; Aksoy \& Karatekin, 2011; Çabuk \& Karacaoğlu, 2003; Erten, 2005; Erol \& Gezer, 2006; Esa, 2010; Gültekin et al., 2008; Gürbüz \& Çakmak, 2012; Karatekin, 2011; Karatekin \& Aksoy, 2012; Kayalı, 2010; Kahyaoğlu et al., 2008; Keser, 2008; Kibert, 2000; Lee, 2008; Malkoç, 2011; Özgen, 2012; Özmen et al., 2005; Sever \& 
Yalçınkaya, 2012; Şama, 2003; Taylor et al., 2007; Timur, 2011; Yıldırım et al., 2012; Yılmaz \& Gültekin, 2012) similar conclusions were reached.

In this study, there has been found a meaningful difference among geography teacher candidates' attitudes towards sustainable environment according to gender variables. Female students attitude scores towards sustainable environment were more than males. There are studies on either sustainable environment attitude or direct environment attitude researches supporting this result. These studies indicate that there is a correspondence between attitude and gender towards environment.

\section{Giriş}

Yapılan araştırmalar aşırı nüfus artışı, sanayileşme ile ortaya çıkan kirlilik, açlık, yoksulluk gibi sorunların olumsuz etkilerini ortaya koymasına rağmen, insanlar yüzyıllardır doğal ve kullanılabilir kaynakların sınırsız olduğunu zannederek yaşamışlardır (Ruff \& Olson, 2009). Günümüzde çevre kuruluşları, devlet yöneticileri, sivil toplum kuruluşları, yazılı ve görsel medya organları, eğitimciler, akademisyenler, üniversiteler vb. birçok kurum ve kuruluş gelecek kuşaklara daha yaşanabilir bir çevre bırakmak gerektiğini daha fazla dile getirmeye başladılar. Tüm bu kurum ve kuruluşlar, çevre sorunlarıyla başa çıkmada ve sürdürülebilir bir çevre bilinci oluşturmada en önemli unsur olarak çevre eğitimini göstermektedirler.

Çevre eğitimi, toplumun tüm kesimlerinde çevre bilincinin ge- 
liştirilmesi, çevreye duyarlı, kalıcı ve olumlu davranış değişiklilerinin kazandırılması ve doğal, tarihi, kültürel, sosyo-estetik değerlerin korunması, aktif olarak katılımın sağlanması ve sorunların çözümünde görev almak olarak tanımlanabilir (Alım, 2006). Çevre için eğitim sadece ekolojik duyarlılığı ve çevre bilinci yüksek, ekobirey yaratmaya yönelik bir eğitim değildir; aynı zamanda sağlıklı yaşama ve sorumluluk alma eğitimidir, aynı zamanda sürdürülebilir hayat, toplumsal gönenç ve küresel barışın teminatıdır. Çevre için eğitim farklı seviye ve karakterdeki ekolojik bilgilerin benimsenmesi ve hayat boyu savunulması ve uygulanmasının yanı sıra; çevre kültürünün, yaşadığı bölge ve ülke, hatta bütün gezegen ve evren için bir sorumluluk duygusunun oluşturulmasına yönelik kesintisiz, yani ömür boyu süren bir eğitim - öğretim sürecidir. Bu süreç duyarlı ve olumlu davranış değişikliği kazandırma süreci olup, temel amacı çevresel sorumluluk bilincine sahip, çevreciliği bir hayat felsefesi olarak benimseyen çevreci dünya vatandaşı yetiştirmektir (Atasoy, 2005).

Tutum, belirli nesne, durum, kurum, kavram ya da diğer insanlara karşı öğrenilmiş, olumlu ya da olumsuz tepkide bulunma eğilimidir (Tezbaşaran, 2008). Sürdürülebilir çevreye yönelik tutum ise çevrenin canlı ve cansız öğeleri ile bunlar arasındaki dengenin varlığının önemine yönelik gösterilen olumlu ya da olumsuz tepkide bulunma eğilimidir (Yıldız, 2011, s.11)

Türkiye'de örgün eğitim çerçevesinde, çevre eğitimine özel bir müfredat bulunmamakla birlikte, çevre ile ilgili temel bilgiler ilkokul, ortaokul ve lise programlarının içinde yer alan farklı dersler (Hayat 
Bilgisi, Sosyal Bilgiler ve Fen Bilgisi, Coğrafya gibi) kapsamında verilmektedir. Yükseköğretime ilişkin olarak da, ulusal olarak benimsenmiş ya da uygulanan belirli bir çevre eğitimi politikası bulunmamaktadır. Üniversiteler, ders programlarını ve içeriklerini kendi kurumsal yapıları içerisinde çözümlemektedirler. Bu nedenle yükseköğretimde, çevre ile ilgili konularda, ulusal ölçekte standart bir eğitim altyapısından ya da uygulamasından bahsetmek olanaklı değildir. Oysa ki Corcoran’a göre (2004) yükseköğretim kurumları, küresel toplumun hayat kalitesinin iyileştirilmesine katkıda bulunacak, gerekli bilgiye, yeteneğe ve değerlere sahip bireylerin yetiştirilmesinden sorumludurlar (akt; Oğuz ve ark., 2011, s.34).

Çevre eğitimi birçok bilim dalı tarafından farklı açılardan incelenmektedir. Ancak bu çalışmalar bilim dallarının sınırlılıkları içerisinde kalmaktadır. Yapılan araştırmalar (Aslan, 2009; Aydın ve ark., 2011; Ballantyne, 1999; Bednarz, 2006; Cecioni, 2005; Demirkaya, 2006; Engin, 2011; Keçeli, 2010) çevre bilinci oluşturmada coğrafya dersinin önemini ortaya koymaktadır. Çevre eğitiminde coğrafya ayrı bir öneme sahiptir. Çünkü coğrafya insan ve çevre arasındaki karşılıklı etkileşimi inceleyen bir bilimdir (Doğanay, 1997, s.39). Ayrıca coğrafya; ekonomik, sosyal ve kültürel dinamikleri anlamada sosyal bilimler (beşeri coğrafya) ve fiziki çevre ve çevresel süreçleri anlamada yer bilimleri (fiziki coğrafya) arasında köprü oluşturan eşsiz bir bilimdir (Alkış, 2009). Su kaynakları, toprak ve bitki örtüsünün kullanımı, arazi kullanımı, yenilenebilir enerji kaynaklarının kullanımı, iklim değişiklikleri ve etkileri, kuraklaşma, çölleşme gibi çevre ile ilgili konular coğrafya biliminin temel konularıdır (Keçeli, 2010). 
Coğrafya eğitiminin, ülkelerin çevre bilinci geliştirmelerinde ve çevre sorunlarına duyarlı vatandaşlar yetiştirmelerinde önemli katkılar sağladığı tartışılmaz bir gerçektir. Bugün kimi ülkelerde Coğrafya eğitimi kimi ülkelerde ise Çevre eğitimi adı altında öğretim programlarında anılan konuların insana vermek istediği temel hedef yaşanabilir bir dünyayı yarının çocuklarına bırakabilmektir (Coşkun ve Aydın, 2011, s.1) Milli Eğitim Bakanlığı Coğrafya Öğretim Programında (2011) çevre konularına önemli ağırlık verilmiştir. Lise coğrafya dersi öğretim programında beş öğrenme alanından biri de "çevre ve toplum" dur ve bütün sınıflarda ortak bir öğrenme alanı olarak kabul edilmiştir. Çevre ve toplum konu alanında doğal kaynakların kullanımı, doğal afetler, çevre sorunları, yönetim ve planlama, çevresel değişim konuları ele alınıp incelenir. Coğrafya öğretim programında (2011) çevre kazanımlarının toplam sayıs1 30'dur (9. ve 10. sinıflarda 3 kazanım, 11. sınıfta 15 kazanım ve 12. sınıfta 9 kazanım). Çevre kazanımlarının genel kazanım içeresindeki oranı \% 20’dir. Bu değerlere göre, coğrafya dersi içerisinde çevre konularının ağırlığının fazla olduğu söylenebilir.

\section{Araştırmanın Amacı}

Öğretmen adaylarının ve üniversite öğrencilerinin çevre tutumlarını ve duyarlılıklarını inceleyen çalışmalar (Aydın, 2010; Çabuk ve Karacaoğlu, 2003; Erol ve Gezer, 2006; Erten, 2005; Gültekin ve ark., 2008; Gürbüz ve Çakmak, 2012; Karatekin ve Aksoy, 2012; Malkoç, 2011; Kayal1, 2010; Kahyaoğlu ve ark., 2008; Keser, 2008; Özgen, 2012; Sever ve Yalçınkaya, 2012; Şama, 2003; Yıldırım ve ark., 2012; Yılmaz ve Gültekin, 2012; Yurt ve ark., 2010) bulunmaktadır. Araş- 
tırma konumuzu oluşturan sürdürülebilir çevreye yönelik tutum çalışmalarının ise (Ruff ve Olson, 2009; Spiropoulou et al., 2007; Tuncer, 2008; Y1ldız, 2011; Tuncer ve ark., 2005, 2006) sınırlı sayıda olduğu tespit edilmiştir.

Yerel, bölgesel ve küresel ölçekte çevre sorunlarının her geçen gün artması, sürdürülebilir çevre eğitimi ve bilincinin kazandırılmasını daha önemli hale getirmekte ve bu durum her kademedeki öğrencilerin sürdürülebilir çevreye yönelik tutumlarının tespit edilip sorunların giderilmesi için çözüm yolları bulma gerekliliğini ön plana çıkarmaktadır. Öğrencilerin çevre eğitimini en verimli bir şekilde alabilecekleri lise kademesinde görev alacak olan coğrafya öğretmen adaylarının ne düzeyde sürdürülebilir çevreye yönelik tutum oluşturduklarının araşt1rılmasının, bu alanda tespit edilen eksikliği dolduracağı düşünülmektedir.

$\mathrm{Bu}$ araştırma ile Coğrafya öğretmen adaylarının sürdürülebilir çevreye yönelik tutumlarının belirlenmesi amaçlanmıştır. Bu temel amaç doğrultusunda aşağıdaki sorulara cevap aranmıştır:

1. Coğrafya öğretmen adaylarının sürdürülebilir çevreye yönelik tutumları nelerdir?

2. Coğrafya öğretmen adaylarının sürdürülebilir çevreye yönelik tutum puanları cinsiyet ve ögrrenim gördükleri sınıf düzeyi değişkenlerine göre anlamlı bir farklılık göstermekte midir? 


\section{Yöntem}

\section{Araştırma Modeli}

$\mathrm{Bu}$ araştırma coğrafya öğretmenliği programında öğrenim gören öğrencilerin sürdürülebilir çevreye yönelik tutumlarını belirlemek amacı ile yapıldığından, tarama modeli kullanılmıştır. Tarama modelleri, geçmişte ya da hâlen var olan bir durumu var olduğu şekliyle betimlemeyi amaçlayan araştırma yaklaşımlarıdır. Araştırmaya konu olan olay, birey ya da nesne, kendi koşulları içinde ve olduğu gibi tanımlanmaya çalışılır. Onları herhangi bir şekilde değiştirme, etkileme çabası gösterilmez. Bilinmek istenen şey vardır ve oradadır. Önemli olan, onu uygun bir biçimde gözleyip belirleyebilmektir (Karasar, 1998, s.77).

\section{Evren ve Örneklem}

Araştırmanın evrenini, Türkiye'deki eğitim fakülteleri coğrafya öğretmenliği programında okuyan coğrafya öğretmen adayları; örneklemini ise 2011-2012 öğretim yılı bahar döneminde, Gazi Üniversitesi Gazi Eğitim Fakültesi Coğrafya Öğretmenliği’nde okuyan öğrenciler oluşturmuştur. Araştırmaya katılan coğrafya öğretmen adaylarının kişisel bilgileri Tablo 1'de gösterilmiştir.

Tablo 1. Araştırmaya Katılan Coğrafya Öğretmen Adaylarının Kişisel Bilgileri 


\begin{tabular}{cccc}
\hline \multirow{2}{*}{ Değişkenler } & Demografik Özellikler & $\begin{array}{c}\text { Ö̆̆grenci } \\
\text { sayısı } \\
(\boldsymbol{n = 1 3 9 )}\end{array}$ & $\begin{array}{c}\text { Yüzde } \\
(\mathbf{\% 1 0 0 )}\end{array}$ \\
\hline \multirow{2}{*}{ Cinsiyet } & Erkek & 84 & 60.4 \\
\cline { 2 - 4 } & Kiz & 55 & 39.6 \\
\cline { 2 - 4 } Sınıf & Birinci Sınıf & 30 & 21.6 \\
\cline { 2 - 4 } & İkinci Sınıf & 35 & 25.2 \\
\cline { 2 - 4 } & Üçüncü Sinıf & 14 & 10.1 \\
\cline { 2 - 4 } & Dördüncü Sınıf & 30 & 21.6 \\
\cline { 2 - 4 } & Beşinci Sinıf & 30 & 21.6 \\
\hline
\end{tabular}

Tablo 1'de görüldüğü gibi, araştırmaya katılan Coğrafya öğretmen adaylarının % 60.4'nü (84 kişi) kızlar, \% 39.6'sını (55 kişi) erkekler oluşturmaktadır. Coğrafya öğretmen adaylarının \% 21.6'sı birinci sınıf, \% 25.2'si ikinci sınıf, \% 10.1'i üçüncü sınıf, \% 21.6's1 dördüncü sınıf ve \% 21.6’sı beşinci sınıf öğrencisidir.

\section{Veri Toplama Aracı}

Araştırmaya katılan coğrafya öğretmen adaylarının sürdürülebilir çevreye yönelik tutumlarını belirlemek amacıyla Yıldız (2011) tarafından geliştirilen anket kullanılmıştır. Anketin güvenirliğini belirlemek için uzman görüşü alınmış ve anketin Cronbach Alpha güvenirlik katsayısı (0.91), KMO katsayısı (0.84), ve Bartlett test değeri (.000) olarak bulunmuştur. Elde edilen bu sonuca göre, ölçeğin güvenilir bir ölçek olduğu ifade edilebilir (Büyüköztürk, 2010). Ölçek 27 maddeden oluşmakta olup Likert tipindedir. Ölçek “tamamen katıllyorum (5)”, “katılıyorum (4)”, “kararsızım (3)”, “katılmıyorum (2)”ve “kesinlikle katılmıyorum (1)"’ şeklinde düzenlenmiş ve puanlanmıştır. 


\section{Verilerin Toplanması ve Analizi}

Araştırmanın verileri, sürdürülebilir çevreye yönelik tutum ölçeğinin 2011-2012 öğretim y1lının bahar döneminde Gazi Üniversitesi Gazi Eğitim Fakültesi Coğrafya Öğretmenliği programında öğrenim gören öğrencilere uygulanması yoluyla elde edilmiştir. Uygulama gönüllülük esası dikkate alınarak yaklaşık 20 dakikada gerçekleşmiştir. Coğrafya öğretmen adaylarının sürdürülebilir çevreye yönelik tutum ölçeği puanlarının analizinde frekans, yüzde, aritmetik ortalama ve standart sapma değerleri kullanılmıştır. Coğrafya öğretmen adaylarının sürdürülebilir çevreye yönelik tutumlarının “cinsiyet” değişkenine göre anlamlı farklılık gösterip göstermediği “Bă̆ımsız Örneklemler İçin t-testi” ile belirlenmiştir. Çalışmaya katılan öğrencilerin sürdürülebilir çevreye yönelik tutumlarının "sınıf düzeyi” değişkenine göre anlamlı farklılığın olup olmadığını belirlemek için “Tek Yönlü Varyans Analizi (ANOVA)" kullanılmıştır. Varyans analizi sonrasında yapılan ikili karşılaştırılmalarda ortaya çıkan istatistiksel farkın hangi gruplar arasında oluştuğunu belirlemek amacıyla "Scheffe testi” kullanılmıştır. Ölçeğin istatistiksel çözümlemelerinde anlamlılık düzeyi 0.05 olarak belirlenmiştir.

\section{Bulgular}

\section{Öğrencilerin Sürdürülebilir Çevreye İlişkin Genel Tutum Puanları}

Araştırmaya katılan coğrafya öğretmen adaylarının sürdürülebilir çevreye yönelik tutumlarının madde bazındaki puanlara ilişkin aritmetik ortalamaları ve standart sapmaları Tablo 2'de verilmiştir. 
Tablo 2. Öğrencilerin Sürdürülebilir Çevreye Yönelik Tutum Ölçeğinden Aldıkları Puanların Ortalama ve Standart Sapmaları

Sürdürülebilir Çevreye Yönelik Tutum Ölçeğinde Yer $\quad \overline{\mathrm{X}} \quad$ SS Alan İfadeler

1. Havayı en az düzeyde kirleten araçlar icat etme dü- 4,287 ,894 şüncesi beni heyecanlandırır.

2. Doğaya bırakılan zararlı gazların doğanın taşıma 4,208 ,928 kapasitesini aşabileceği düşüncesi beni korkutur.

3. Atmosferde artan kirliliğin, küresel iklim değişikliği- 4,079 1,007 nin nedeni olduğunu bilmek beni korkutuyor.

4. Gelecekte yaşanacak olan su yetersizliğinin nedenle- 4,007 1,073 rinden birisinin insan nüfusundaki artış olması beni endişelendirir.

5. Suyun gelecek nesillere devamlılığını sağlamak için 4,302 ,914 kirliliğe neden olan tarım ilaçlarının, sanayi ürünlerinin ve evde temizleyicilerin az kullanılmasını tercih ederim.

6. Ürünlerde biriken kimyasalın besin zincirinin diğer 4,273,915 halkalarında yaratacağı olumsuz etki canımı sıkar.

7. Dünyanın diğer bölgelerinde yaşanan toprak kaybı 4,330 1,072 beni ilgilendirmez.

8. Geleceği düşünerek yenilenebilir enerji kaynaklarına 4,597 ,922 yatırım yapmak gereksizdir.

9. Enerji kaynaklarının sürdürülebilirliğini sağlamak için 4,654 ,831 bu kaynakları dikkatli kullanma düşüncesi gereksizdir.

10. Fosil enerji kaynaklarının bir gün tükenebileceğini 4,539 934 düşünerek, bu kaynakları dikkatli kullanmak gereksizdir.

11. Hızla tükettiğimiz kaynakları doğanın yenileyeme- 4,179 1,051 yeceği düşüncesi beni endişelendirir.

12. Sürdürülebilir çevre için yapılan geri dönüşüm rek- 4,417 806 lamlarını görünce sevinirim.

13. Aldığım ürünlerin ambalajları üzerinde geri dönü- 3,208 1,163 şüm ambleminin olmasına dikkat etmem.

14. Okullarda geri dönüşüm ile ilgili eğitim verilmesini 4,510 ,837 gerekli buluyorum.

15. Depozito işleminin uygulandığ kullanmayı tercih ederim. 
16. Poşet kullanmak yerine bez torba, file, kese kağıtla- 3,194 1,184 rını kullanmayı tercih etmem.

17. Aldığım ürünlerin tek kullanımlık değil de çok kul- 3,554 1,336 lanımlık olmasına dikkat etmem.

18. Çevrede geri dönüşüm kutularını yeteri kadar gör- 4,618 ,695 memek üzücü bir durum.

19. Hızla artan tüketimin çevrenin sürdürülebilirliği $4,374,853$ önünde önemli bir engel olması beni korkutur.

20. Doğanın bize verebileceğinden fazlasını tükettiğimiz 4,388 1,032 zaman geleceğin bu durumdan etkileneceğini düşünmek gereksizdir.

21. Sürdürülebilirlik için tüketim alışkanlıklarını konu 4,036 ,837 alan seminerlere katılmaktan mutlu olurum.

22. İnsan nüfusu artınca kaynakların tükeneceği düşün- 4,057 1,178 cesi gereksizdir.

23. İnsan nüfusundaki artışın, doğal dengenin sürdürü- 4,467 845 lebilirliğine engel olması beni ilgilendirmez.

24. Sürdürülebilirlik ile ilgili öğrendiklerimi aileme ve 4,489 854 yakın çevreme anlatmak zaman kaybıdır.

25. Çocuklarımıza iyi bir çevre bırakabilmek için sür- 4,395 ,738 dürülebilirliğin hayat felsefesi olması hoşuma gider.

26. İnsanların geri dönüşüm uygulamaları ile ham madde 4,438 ,799 ihtiyacını karşılayıp doğa üzerindeki baskılarını azaltmalarına sevinirim.

27. Uygulanan geri dönüşüm kampanyaları ile doğal 4,611 ,619 kaynakların sonsuz olmadığının insanlara anlatılmasını önemli buluyorum.

Toplam $4.2230,937$

Tablo 2'de görüldüğü gibi, öğrencilerin sürdürülebilir çevreye yönelik tutum ölçeğinin aritmetik ortalaması 4.22 ve standart sapması 0.93 olarak saptanmıştır. Bu bulguya göre, Çalışmaya katılan coğrafya öğretmen adaylarının sürdürülebilir çevreye yönelik tutumları olumlu ve yüksek düzeydedir.

Araştırmaya katılan öğrencilerin sürdürülebilir çevreye yönelik 
tutum ölçeğine verdikleri cevaplarda aritmetik ortalaması en yüksek olan maddeler şunlardır:

1. "Enerji kaynaklarının sürdürülebilirliğini sağlamak için bu kaynakları dikkatli kullanma düşüncesi gereksizdir.” (9. madde, $\overline{\mathrm{X}}$ $=4,6547, \mathrm{SS}=0,83155)$. Bu maddeye coğrafya öğretmen adaylarının \% 78.4'ü (109 kişi) “kesinlikle katılmıyorum”, \% 15.8'i (22 kişi) "katılmıyorum" cevabını verirken sadece 4 öğrenci bu tutum ifadesine katıldığını belirtmiştir.

2. “Çevrede geri dönüşüm kutularını yeteri kadar görmemek üzücü bir durum.” (18. madde, $\overline{\mathrm{X}}=4.6187, \mathrm{SS}=0.69570)$. Bu maddeye öğrencilerin \% 69.8'i (97 kişi) “kesinlikle katılıyorum”, \% 25.9’u (36 kişi) "kat1lıyorum”, \% 1.4'ü (2 kişi) “fikrim yok”, \% 2.2'si (3 kişi) "katılmıyorum" ve 1 öğrenci ise "kesinlikle katılmıyorum” şeklinde cevap vermişlerdir.

3. "Uygulanan geri dönüşüm kampanyalart ile doğal kaynakların sonsuz olmadığının insanlara anlatılmasını önemli buluyorum.” (27. madde, $\bar{X}=4,6115$, SS=0.61985). Çalışmaya katılan öğrencilerin \% 66.2'si bu ifadeye “kesinlikle katıldığını”, \% 30.9'u ise “katıldığını” belirtmiştir.

Çalışmaya katılan coğrafya öğretmen adaylarının sürdürülebilir çevreye yönelik tutum ölçeğine verdikleri cevaplarda aritmetik ortalaması en düşük olan maddeler şunlardır:

1. "Poşet kullanmak yerine bez torba, file, kese kâğttlarını kullanmayı tercih etmem." (16. madde, $\overline{\mathrm{X}}=3,1942$, SS=1,18492). Bu 
ifadeye 9 öğrenci (\% 6.5) kesinlikle katıldığını, 36 öğrenci (\% 25.9) katıldığını, 36 öğrenci (\% 25.9) fikrinin olmadığını, 35 öğrenci (\% 25.2) katılmadığını ve 23 öğrenci (\% 16.5) kesinlikle katılmadığını belirtmişlerdir.

2. “Aldığım ürünlerin ambalajlarl üzerinde geri dönüşüm ambleminin olmasina dikkat etmem." (13. madde, $\overline{\mathrm{X}}=3.2086$, $\mathrm{SS}=1,16392)$

3. “Aldığım ürünlerin tek kullanımlık değil de çok kullanımlık olmasina dikkat etmem.” (17. madde, $\overline{\mathrm{X}}=3.554, \mathrm{SS}=1,33608)$

\section{Coğrafya Öğretmen Adaylarının Sürdürülebilir Çevreye Yönelik Tutumlarının “Cinsiyet” Değişkenine Göre Karşılaştırılması}

Coğrafya öğretmen adaylarının sürdürülebilir çevreye yönelik tutum puanları ile cinsiyetleri arasında anlamlı bir farklılığın olup olmadığı bağımsız örneklemler için t-testi ile belirlenmiş ve sonuçları Tablo 3’de gösterilmiştir.

Tablo 3. Öğrencilerin Sürdürülebilir Çevreye Yönelik Tutum Ölçeğinden Aldıkları Puanların Cinsiyet Değişkenine Göre Bağımsız Gruplar T-Testi Sonuçları

\begin{tabular}{ccccccc}
\hline Değişken & $n$ & $X$ & $S S$ & $S d$ & $t$ & $p$ \\
\cline { 1 - 4 } K1z & 55 & 119,0545 & 10,14235 & \multirow{2}{*}{137} & 3,473 & \multirow{2}{*}{, $001^{*}$} \\
\cline { 1 - 4 } Erkek & 84 & 110,7262 & 15,76511 & & & \\
\hline
\end{tabular}

$* \mathrm{p}<0,05$

Tablo 3 incelendiğinde; kız öğrencilerin sürdürülebilir çevreye yönelik tutum ölçeğinden aldıkları puanların ortalamasının 119.054, 
erkek öğrencilerin ise ortalamasının 110.726 puan olduğu görülmektedir. Bağımsız gruplar için yapılan t-testi sonuçlarına göre; öğrencilerin cinsiyetleri ile sürdürülebilir çevreye yönelik tutum puanları arasında anlamlı bir fark bulunmuştur [t(137)=3.473; $p<.0 .05] . \mathrm{Bu}$ bulgu, coğrafya öğretmen adaylarının coğrafya öğretimine ilişkin tutumları ile cinsiyet değişkeni arasında anlamlı bir ilişkinin olduğu şeklinde de yorumlanabilir.

\section{Coğrafya Öğretmen Adaylarının Sürdürülebilir Çevreye Yönelik Tutumlarının “Sınıf Düzeyi” Değişkenine Göre Karşılaştırılması}

Araştırmaya katılan coğrafya öğretmen adaylarının, sürdürülebilir çevreye yönelik tutum puanlarının sınıf düzeyine göre ANOVA sonuçları Tablo 4'de verilmiştir.

Tablo 4. Coğrafya öğretmen adaylarının sürdürülebilir çevreye yönelik tutum puanlarının sınıf düzeyi değişkenine göre ANOVA sonuçları

\begin{tabular}{|c|c|c|c|c|c|c|c|}
\hline Değişken & Kat & gori & $\overline{\mathbf{N}}$ & $\overline{\mathrm{X}}$ & & 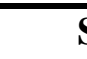 & \\
\hline \multirow{9}{*}{ Sinıf Düzeyı } & Birinc & Sinif & 30 & 120 , & & & 775 \\
\hline & İkinc & Sinif & 35 & 111 , & & & 749 \\
\hline & Üçünc & Sinif & 14 & 117 , & & & 237 \\
\hline & Dördün & ü Sınıf & 30 & 108, & & & 781 \\
\hline & Beşinc & Sinif & 30 & 115, & & & 644 \\
\hline & $\begin{array}{c}\text { Varyansın } \\
\text { Kaynağı }\end{array}$ & $\begin{array}{l}\text { Kareler } \\
\text { Toplamı }\end{array}$ & sd & $\begin{array}{c}\text { Kareler } \\
\text { Ort. }\end{array}$ & & $\mathbf{p}$ & $\begin{array}{l}\text { Anlaml } \\
\text { Fark }\end{array}$ \\
\hline & $\begin{array}{c}\text { Gruplar } \\
\text { Aras1 }\end{array}$ & 2771,80 & 4 & 692,95 & 3,611 & ,008* & \multirow{3}{*}{$\begin{array}{c}\text { Birinci } \\
\text { Sinıflar } \\
\text { Dördüncü } \\
\text { Siniflar }\end{array}$} \\
\hline & $\begin{array}{c}\text { Gruplar } \\
\text { İçii }\end{array}$ & 25717,13 & 134 & 191,91 & & & \\
\hline & Toplam & 28488,93 & 138 & & & & \\
\hline
\end{tabular}

${ }^{*} \mathrm{p}>0.05$ 
Tablo 4 incelendiğinde; birinci sınıfların sürdürülebilir çevreye yönelik tutum puan ortalamasının 120.233, ikinci sınıfların 111.114, üçüncü sınıfların 117.214, dördüncü sınıfların 108.000 ve beşinci s1nıfların sürdürülebilir çevreye yönelik tutum puan ortalamasının 115.733 olduğu görülmektedir. Gruplar arasında istatistiksel açıdan anlamlı farklılığın olup olmadığını belirlemek için yapılan "ANOVA” sonucuna göre; coğrafya öğretmen adaylarının sürdürülebilir çevreye yönelik tutum puanları, sınıf düzeyine bağlı olarak anlamlı bir farklılık göstermiştir. $\left[\mathrm{F}_{(4,134)}=3.611 ; \mathrm{p}<0.05\right]$. Bu farkın hangi grupların ortalamaları arasındaki farktan kaynaklandığını belirlemek için "Scheffe testi” uygulanmış ve analiz sonucunda birinci sınıflar ile dördüncü sınıfların sürdürülebilir çevre tutum puanları arasında anlamlı farklılık tespit edilmiştir.

\section{Tartışma ve Sonuç}

Dünyayı ve bütün insanlığın geleceğini ilgilendiren sorunlara karş1 duyarlılık çok büyük önem arz etmektedir. Dünya nüfusunun hızla artışı, doğal kaynakların özensizce tüketilmesi, ormanların tahribi, hava-su-toprak-gürültü kirliliği, insan hakları ihlalleri, kentleşme, birçok yerde diş ve iç savaşların yaşanması, açlık, kıtlık, ekonomik dengelerdeki uyumsuzluk, işsizlik gibi ciddi sorunlar bir küresel köy haline gelen dünyamızın artık başa çıkmakta çok zorlandığı ve ortak katılımlarla çözülmesi gereken sorunlardır. Yerel sorunların bazıları, artık yerel olmaktan çıkmış ve başka bölgeleri de etki altına almıştır. Üstelik, bir sorun bir başka sorunu doğurmaktadır. Örneğin Lerner ve Lerner (2003)'in ifade ettiği gibi ormanların tahribat1; iklimlerin de- 
ğişmesi, kurak mevsim süresinin uzaması, su baskınları, erozyon, bitki ve hayvan türlerinin yok olması gibi başka birçok çevre ile ilgili sorunun ortaya çıkmasındaki en önemli etkenlerden biridir. Bütün bunları yok saymak, ögrencileri bu sorunlardan soyutlamak realiteye sığmayacaktır. Bu nedenle, ülkemiz de dâhil olmak üzere birçok ülkede dünyayı ilgilendiren çevre konuları öğretim programlarına alınarak, çocuk ve gençlerimizin farkındalıklarının geliştirilmesi amaçlanmaktadır. Bu bağlamda 2010 Küresel Boyut Konferans1 (Global Dimension Conference)'nda eğitimcilerin en çok kültürel çeşitlilik, yerel-küresel bağlantılar ve küresel bir toplumda yaşayamaya hazırlanma temaları üzerinde durmuşlardır. Bunu sağlamak için yapılması gerekenler ise; öğrenci ve öğretmenlere okul giriş kapısı ve yerel halkın dışında kalanlarla etkileşim firsatı verme, öğrencilere bir dünya vatandaşı olma olanağı sağlama ve böylece etrafının farkına vararak ona karş1 sorumluluk hissetme, her şeye, sadece kendi bakış açısından değil, başkalarının gözüyle de bakma yeteneği kazandırmadır (Bourne \& Hunt, 2011, s. 20).

$\mathrm{Bu}$ araştırmada coğrafya öğretmen adaylarının sürdürülebilir çevreye ilişkin tutumlarının ne düzeyde olduğu tespit edilmiştir. Ayrıca çalışmaya katılan coğrafya öğretmen adaylarının sürdürülebilir çevreye yönelik tutumları cinsiyet ve sınıf düzeyi açısından da ele alınmıştır. Çalışmada coğrafya öğretmen adaylarının sürdürülebilir çevreye yönelik tutumları olumlu ve yüksek düzeyde olduğu belirlenmiş̧tir. $\mathrm{Bu}$ sonuç sevindirici bir durum olarak değerlendirilebilir. Araştırmaya katılan bu öğrenciler çevre konularının oldukça fazla yer aldığı coğrafya dersinin öğretiminde görev alacak olan çevreye duyarlı öğret- 
menler olacaklardır. Dolayısıyla öğrencilerine bilinçli çevre eğitimi vererek sürdürülebilir bir dünya için katı sağlayacaklardır. Farklı örneklemler üzerinde yapılan sürdürülebilir çevreye ilişkin tutum çalışmalarında (Ruff ve Olson, 2009; Şahin ve Erkal, 2010; Tuncer, 2008; Tuncer ve ark., 2005, 2006; Yıldız, 2011) ve üniversite öğrencilerinin çevreye ilişkin tutumlarını, duyarlılıklarını ve okuryazarlıklarını belirleyen araştırmalarda da (Akbaş, 2007; Aksoy ve Karatekin, 2011; Aydın, 2010; Aydın ve Çepni, 2010; Altınöz, 2011; Çabuk ve Karacaoğlu, 2003; Erol ve Gezer, 2006; Esa, 2010; Erten, 2005; Gültekin ve ark., 2008; Gürbüz ve Çakmak, 2012; Kahyaoğlu ve ark., 2008; Karatekin, 2011; Karatekin ve Aksoy, 2012; Kayal1, 2010; Keser, 2008; Kibert, 2000; Lee, 2008; Malkoç, 2011; Özgen, 2012; Sever ve Yalçınkaya, 2012; Şama, 2003; Taylor ve ark., 2007; Timur, 2011; Y1ld1rım ve ark., 2012; Yılmaz ve Gültekin, 2012) benzer sonuca ulaşıllmış ve bu çalışmalara katılan öğrencilerin çevreye yönelik olumlu tutuma sahip oldukları belirlenmiştir. Örneğin Yıldız (2011) çalışmasında 213 öğretmen adayının (Dokuz Eylül Üniversitesi fen bilgisi öğretmen adayları) sürdürülebilir çevre tutum puanlarının ortalamasını $\overline{\mathrm{X}}=115$ olarak belirlenmiş ve tutum puanlarının iyi seviyede ve olumlu yönde olduğu tespit edilmiştir. Aydın ve Çepni (2010) tarafından Karabük Üniversitesinde öğrenim gören 931 öğrenci üzerinde gerçekleştirilen çalışmada üniversite öğrencilerinin çevre sorunlarına yönelik olumlu tutuma sahip oldukları ortaya konulmuştur. Özgen (2012) çalışmasında; sınıf, sosyal bilgiler, fen bilgisi ve matematik öğretmen adaylarının $(\mathrm{n}=727)$ çevre sorunlarına yönelik tutumlarının 3 kategoride kümelendiği tespit edilmiştir. Malkoç (2011) tarafından 377 sınıf öğretmeni 
adayı üzerinde gerçekleştirilen çalışmada sınıf öğretmeni adaylarının çevre sorunlarına yönelik tutumları ile bilişsel farkındalık becerileri arasında paralel ilişki olduğu tespit edilmiştir. Aydın (2010) tarafından coğrafya öğretmen adaylarının çevre sorunlarına ve çevre eğitimine ilişkin görüşlerini incelenen çalışmada coğrafya öğretmen adaylarının, çevre sorunları ve çevre eğitimi hakkındaki sosyal ve akademik duyarlılıklarının yüksek düzeyde olduğu tespit edilmiştir.

$\mathrm{Bu}$ çalışmada, coğrafya öğretmen adaylarının sürdürülebilir çevreye yönelik tutumları cinsiyet değişkenine göre anlamlı farklılık göstermişstir. Kız öğrencilerin sürdürülebilir çevreye ilişkin tutum puanları erkeklere göre daha fazladır. Bu sonucu destekleyen gerek sürdürülebilir çevre tutum çalışmaları gerekse doğrudan çevre tutum araştırmaları (Aydın ve Çepni, 2010; Connell ve ark., 1998; Çubuk ve Karacaoğlu, 2003; Erol ve Gezer, 2006; Gürbüz ve Çakmak, 2012; Kayalı, 2010; Keser, 2008; Loughland ve ark., 2003; Özgen, 2012; Şama, 2003; Teksöz ve ark., 2010; Tuncer, 2008) bulunmaktadır. Yapılan bu araştırmalar çevreye ilişkin tutum ile cinsiyet arasında bir ilişkinin olduğunu göstermektedir. Örneğin; Erol ve Gezer (2006), sınıf öğretmeni adaylarının çevresel tutumlarını inceledikleri araştırmalarında, kız öğrencilerin erkek öğrencilere göre çevresel sorunlara yönelik daha olumlu tutumlar içinde oldukları sonucuna varmışlardır. Kayalı (2010), öğretmen adaylarının çevre sorunlarına yönelik tutumlarını incelediği çalışmasında yine kız öğrencilerin erkek öğrencilere göre daha olumlu çevresel tutuma sahip olduklarını belirtmiştir. Tikka, Kuitunen ve Tynys' in (2000) de belirttiği gibi kadınlar doğaya yönelik daha güçlü duyarlılığa sahip iken erkekler daha çok doğaya hükmet- 
meye ve doğal kaynaklardan fayda sağlamaya yatkındırlar. Bu açıdan, çevreye yönelik tutumlar ve çevre ile ilgili kullanımlar boyutlarında bayanlar lehine cinsiyet farkının tespit edilmesi beklenen bir sonuçtur (Teksöz ve ark., 2010). Şama (2003), üniversite öğrencilerinin çevresel tutumlarını incelediği araştırmasında, kız öğrencilerin erkek öğrencilere göre çevre sorunlarına yönelik daha olumlu tutumlar içinde olduğu sonucuna varmıştır. Ayrıca Şama (2003) kız öğrencilerin ilerleyen zamanda birer anne adayı olmaları bakımından bu sonucun olumlu olarak değerlendirilebileceğini dile getirmiştir. Öğretmen adaylarının çevresel tutumları üzerinde cinsiyetin belirleyici rolünün bulunmadığını ortaya koyan araştırmalar da (Aydın, 2010; Malkoç, 2011; Sever ve Yalçınkaya, 2012; Y1ldırım ve ark., 2012; Yurt ve ark., 2010) bulunmaktadır.

Araştırmaya katılan coğrafya öğretmen adaylarının, sürdürülebilir çevreye yönelik tutum puanları sınıf düzeyine farklılık göstermiştir. Yapılan analiz sonucunda birinci sınıflar ile dördüncü sınıfların sürdürülebilir çevre tutum puanları arasında anlamlı farklılık tespit edilmiştir. Birinci sınıfların sürdürülebilir çevre tutum puanlarının diğer bütün sınıflardan daha yüksek çıkması düşündürücü bir sonuçtur. Sınıf düzeyi ile çevre tutumu arasında manidar bir ilişkinin olduğunu ortaya koyan çalışmalar bulunmaktadır. Yıldırım ve ark., (2012) tarafından Amasya Üniversitesinde farklı programlarda öğrenim gören öğretmen adaylarının çevre tutumları sınıf düzeyine göre anlamlı bir şekilde farklılaşmıştır. Çabuk ve Karacaoğlu (2003) tarafından yapılan çalışmada, 4. sınıf öğretmen adaylarının diğer sınıflarda öğrenim gören öğretmen adaylarından daha yüksek düzeyde çevre tutuma sahip ol- 
duğu sonucuna ulaş1lmıştır.

Araştırmada elde edilen bulgular dikkate alınarak şu önerilere yer verilmiştir. Coğrafya öğretmenliği lisans programında öğrencilere daha etkili ve bilinçli sürdürülebilir çevre eğitimi verilmelidir. Bunun için coğrafya öğretmen adaylarının çevre projelerinde (doğa eğitimi gibi) görev almaları sağlanmalı, derslerde çevre bilinci kazandıracak etkinliklere yer verilmeli ve öğrencilerin yaparak yaşayarak öğrenmelerine imkân sağlayacak eğitim ortamları düzenlenmelidir. Çevre eğitimi konusunda akademik çalışmalara destek verilmeli ve bu alanda yapılan çalışmalar proje desteği veren kuruluşlar tarafından desteklenmelidir. Coğrafya öğretmenliği lisans ve lisansüstü ders müfredatları sürdürülebilir çevre eğitimi konuları ve dersleri dikkate alınarak hazırlanmalıdır. Ayrıca, öğretim programlarında çevre eğitimi konuları aşamalı bir şekilde verilmeli ve öğrencilerin gelişim düzeyleri mutlaka dikkate alınmalıdır. $\mathrm{Bu}$ çalışma Gazi Üniversitesi Gazi Eğitim Fakültesi Coğrafya Öğretmenliği lisans programına devam eden öğrenciler üzerinde gerçekleştirilmiştir. Araştırmanın sonuçlarını karşılaştırmak ve güvenirliliğini arttırmak için araştırmanın örneklemi genişletilebilir. $\mathrm{Bu}$ çalışmada birinci sınıf coğrafya öğretmen adaylarının sürdürülebilir çevre tutum puanları diğer sınıflardan yüksek çıkmıştır. Bu düşündürücü durumun nedenleri nitel araştırmalarla ortaya çıkarılabilir. Coğrafya öğretmenlerinin de sürdürülebilir çevre tutumları araştırılabilir.

\section{Kaynakça}

Alım, M. (2006). Avrupa birliği üyelik sürecinde Türkiye'de çevre ve ilköğretimde çevre eğitimi. Kastamonu Ĕgitim Dergisi, 14(2), 
599-616.

Atasoy, E. (2005). Çevre için ĕgitim: Illkögretim öğrencilerinin çevresel tutum ve çevre bilgisi üzerine bir çalışma. Yayımlanmamış doktora tezi, Uludağ Üniversitesi Sosyal Bilimler Enstitüsü.

Akbaş, T. (2007). Fen bilgi öğretmen adaylarında çevre olgusunun araştırılması. Yayınlanmamış yüksek lisans tezi, Atatürk Üniversitesi Fen Bilimleri Enstitüsü.

Aksoy, B. ve Karatekin, K. (2011). Faklı programlardaki lisans öğrencilerinin çevreye yönelik duyuşsal eğilimleri. Türkiye Sosyal Araştırmalar Dergisi, 15(3), 23-36.

Alkış, S. (2009). Sürdürülebilir bir dünya için coğrafya eğitimi. İstanbul: Aktif Yayınevi.

Altınöz, N. (2010). Fen bilgisi öğretmen adaylarının çevre okuryazarlık düzeyleri. Yayımlanmamış yüksek lisans tezi, Sakarya Üniversitesi Fen Bilimleri Enstitüsü.

Aslan, A. (2009). Ortaöğretim coğrafya dersi programındaki çevre konularının analizi. Yayınlanmamış yüksek lisans tezi. Marmara Üniversitesi Eğitim Bilimleri Enstitüsü.

Aydın, F. (2010). Coğrafya öğretmen adaylarının çevre sorunları ve çevre eğitimi hakkındaki görüşleri (Gazi Üniversitesi Örneği). International Online Journal of Educational Sciences (IOJES), 2(3), 818-839. 
Aydın, F. ve Çepni, O (2010). University students’ attitudes towards environmental problems: A case study from Turkey. International Journal of the Physical Sciences, 5(17), 2715-2720.

Aydın, F., Kaya, H. ve Coşkun, M. (2011). The role of geography course in building environmental conscious. World Applied Sciences Journal, 12(6), 822-829.

Ballantyne, R. (1999): Teaching environmental concepts, attitudes and behaviour through geography education: findings of an international survey, International Research in Geographical and Environmental Education, 8(1), 40-58

Bednarz, R. S. (2006): Environmental research and education in US geography. Journal of Geography in Higher Education, 30(2), 237-250.

Büyüköztürk, Ş. (2010). Sosyal bilimler için veri analizi el kitabı. Ankara:PegemA Yayıncılı.

Bourne, D. ve Hunt, F. (2011). Global dimension in secondary schools development. Education Research Centre, Research Paper, (1).

Cecioni, E. (2005). Environmental education and geography of complexity. International Research in Geographical and Environmental Education, 14(4), 277-294.

Connell, S., Fien, J., Lee, J., Sykes, H. ve Yencken, D. (1998) 'If it doesn’t really affect you, you don’t think about it.' A qualitative 
study of young people's environmental attitudes in two Australian cities. Environmental Education Research, 4 (3), 95-113.

Coşkun, M. ve Aydın, F. (2011). Geography teacher candidates’ perceptions towards the "greenhouse effect". American - Eurasian Journal of Agriculture \& Environment Sciences, 10(2), 290-295.

Çabuk, B. ve Karacaoğlu, C (2003). Üniversite öğrencilerinin çevre duyarlılıklarının incelenmesi. Ankara Üniversitesi Eğitim Bilimleri Fakültesi Dergisi, 36(1-2), 189-198.

Demirkaya, H. (2006). Çevre eğitiminin Türkiye'deki coğrafya programları içerisindeki yeri ve çevre eğitimine yönelik yeni yaklaşımlar. Fırat Üniversitesi Sosyal Bilimler Dergisi, 16(1), 207-222.

Doğanay, H. (1997). Coğrafya 'ya giriş. İstanbul: Öz Eğitim Yayınları.

Engin, H. (2010). Coğrafya eğitiminde sürdürülebilir kalkınma, sürdürülebilirlik ĕgitimi ve çevre eğitimi konularının kazandırılması. Yayımlanmamış yüksek lisans tezi, Marmara Üniversitesi Eğitim Bilimleri Enstitüsü.

Erol G. H. ve Gezer, K. (2006). Sınıf öğretmenliği öğretmen adaylar1nın çevreye ve çevre sorunlarına yönelik tutumları. International Journal of Environmental and Science Education. 1(1), 65-77. 
Erten, S. (2005). Okul öncesi öğretmen adaylarında çevre dostu davranışların araştırılması. Hacettepe Üniversitesi Eğitim Fakültesi Dergisi, 28, 91-100.

Esa, N. (2010). Environmental knowledge, attitude and practices of student teachers. International Research in Geographical and Environmental Education, 19(1), 39-50.

Gültekin, M., Y1lmaz, F., \& Dal, S. (2008, May).Sürdürülebilir kalkınma ve çevre eğitimine ilişkin öğretmen adaylarının görüşleri: Anadolu Üniversitesi Örneği. . Viii. ulusal sınıf öğretmenliği sempozyumu. Çanakkale 18 Mart Üniversitesi, Çanakkale.

Gürbüz, H. ve Çakmak, M. (2012). Biyoloji bölümü öğrencilerinin çevreye yönelik tutumlarının incelenmesi. Dicle Üniversitesi Ziya Gökalp Eğitim Fakültesi Dergisi, 19, 162-173.

Kahyaoğlu, M., Daban, Ş.ve Yangın, S. (2008). İlköğretim öğretmen adaylarının çevreye yönelik tutumları. Dicle Üniversitesi Ziya Gökalp Eğitim Fakültesi Dergisi, 11, 42-52.

Karatekin, K. (2011). Sosyal bilgiler ögretmen adaylarının çevre okuryazarlık düzeylerinin belirlenmesi. Yayımlanmamış doktora tezi, Gazi Üniversitesi Eğitim Bilimleri Enstitüsü.

Karatekin, K. ve Aksoy, B. (2012). Sosyal bilgiler öğretmen adaylar1nın çevre okuryazarlık düzeylerinin çeşitli değişkenler açısından incelenmesi. Turkish Studies, 7(1), 1423-1438. 
Kayalı, H. (2010). Sosyal bilgiler, Türkçe ve sınıf öğretmenliği öğretmen adaylarının çevre sorunlarına yönelik tutumları. Marmara Coğrafya Dergisi, 21, 258-268.

Keser, S. (2008). Fen bilgisi öğretmen adaylarının çevreye karşı tutumları. Yayınlanmamış yüksek lisans tezi, Abant izzet Baysal Üniversitesi Sosyal Bilimler Enstitüsü.

Kibert, N. C. (2000). An analysis of the correlations between the attitude, behavior, and knowledge components of environmental literacy in undergraduate university students. Yayınlanmamış yüksek lisans tezi, The Graduate School of the University Of Florıda, USA.

Lee, B.E. (2008). Environmental attitudes and information sources among African American college students. The Journal of Environmental Education, 40(1), 29-42.

Lerner, B. W. ve Lerner, K. L. (2003). Forests and deforestration. World of Earth Science, 1, 226.

Loughland, T., Reid, A., Walker, K. ve Petocz, P. (2003). Factors influencing young people's conceptions of environment. Environmental Education Research, 9(1), 3-20.

Malkoç, H. (2011). Sınıf öğretmeni adaylarının çevre sorunlarına yönelik tutumlarının ve bilişsel farkındalık becerilerinin incelenmesi. Yayımlanmamış yüksek lisans tezi, Gazi Üniversitesi Eğitim Bilimleri Enstitüsü. 
MEB (2011). Coğrafya dersi öğretim programı (9, 10, 11 ve 12. Stniflar)

Oğuz, D., Çakıc1, I. ve Kavas, S. (2011). Yükseköğretimde öğrencilerin çevre bilinci. Süleyman Demirel Üniversitesi Orman Fakültesi Dergisi, 12, 34-39.

Özgen, N. (2012). Öğretmen adaylarının çevre sorunlarına yönelik tutumlar1: Türkiye örneği. Kastamonu Eğitim Dergisi, 20(2), 403-422.

Ruff C. L. ve Olson M.A. (2009). The attitudes of interior design students towards sustainability. International Journal of Technology and Design Education, 19(1), 67-77.

Sama, E. (2003). Öğretmen adaylarının çevre sorunlarına yönelik tutumları. Gazi Üniversitesi Gazi Eğitim Fakültesi Dergisi, 23(2), 99-110.

Sever, R. ve Yalçınkaya, E. (2012). Sınıf öğretmeni adaylarının çevresel tutumlarının incelenmesi. Marmara Coğrafya Dergisi, 26, $1-15$.

Spiropoulou, D., Antonakaki, T., Kontaxaki, S., ve Bouras, S. (2007). Primary teachers' literacy and attitudes on education for sustainable development. Journal of Science Education and Technology, 16, 443-450.

Şahin, H. ve Erkal, S. (2010). The attitudes of middle school students 
towards the environment. Social Behavior and Personality, 38(8), 1061-1072.

Taşl1 Keçeci, Ö. (2010). Ortaöğretim coğrafya derslerinin çevre bilinci oluşturmadaki rolünün ögrenci görüşlerine değerlendirilmesi (Aydın Örneği). Yayınlanmamış yüksek lisans tezi, Atatürk Üniversitesi Sosyal Bilimler Enstitüsü.

Taylor, N., Nathan, S. ve Coll, R. (2003). Education for sustainability in regional new south wales, Australia: an exploratory study of some teachers' perceptions. International Research in Geographical and Environmental Education, 12(4), 291-311.

Teksöz, G., Şahin, E. ve Ertepınar, H. (2010). Çevre okuryazarlığı, öğretmen adayları ve sürdürülebilir bir gelecek. Hacettepe Üniversitesi Eğitim Fakültesi Dergisi, 39, 307-320.

Tezbaşaran, A. (2008). Likert tipi ölçek hazırlama kılavuzu (3. bask1). e-kitap.

Timur, S. (2011). Fen bilgisi öğretmen adaylarının çevre okuryazarlık düzeylerinin belirlenmesi. Yayımlanmamış doktora tezi, Gazi Üniversitesi Eğitim Bilimleri Enstitüsü.

Tuncer, G. (2005). Young attitude on sustainable development: a case study. Hacettepe Üniversitesi Ĕgitim Fakültesi Dergisi, 29, 187-193.

Tuncer, G. (2008). University students' perception on sustainable de- 
velopment: a case study from Turkey. International Research in Geographical and Environmental Education, 17(3), 212-226.

Tuncer, G., Tekkaya, C. ve Sungur, S. (2006). Öğretmen adaylarının sürdürülebilir kalkınma ile ilgili inançları: cinsiyet ve çevre dersine katılımın etkisi. Hacettepe Üniversitesi Eğitim Fakültesi Dergisi, 31, 179-187.

Yıldırım, C., Bacanak, A. ve Özsoy, S. (2012). Öğretmen adaylarının çevre sorunlarına yönelik duyarlılıkları. Kastamonu Eğitim Dergisi, 20(1), 121-134.

Yıldız, Ş. (2011). Öğretmenlerin, öğretmen adaylarının ve ögrencilerin sürdürülebilir çevre ile ilgili kavramsal anlamaları ve tutumları. Yayımlanmamış yüksek lisans tezi, Dokuz Eylül Üniversitesi, Eğitim Bilimleri Enstitüsü.

Yılmaz, F. ve Gültekin, M. (2012). Sınıf öğretmeni adaylarının çevre sorunları bağlamında öğrenim gördükleri programa ilişkin görüşleri. Dicle Üniversitesi Ziya Gökalp Eğitim Fakültesi Dergisi, 18, 120-132.

Yurt, Ö., Kalburan, N. ve Kandır, A. (2010). Investigation of the environmental attitudes of the early childhood teacher candidates. Procedia Social and Behavioral Sciences, 2, 4977-4984 
